\title{
SPECIFICS OF EVOKED COGNITIVE POTENTIALS P300 IN CHRONIC BRAIN ISCHEMIA
}

\author{
${ }^{1}$ Prof. E.N.Majidova*, ${ }^{2}$ D.A.Haydarova \\ ${ }^{1}$ Tashkent Medical Institute of Pediatrics, Tashkent, Uzbekistan \\ ${ }^{2}$ Tashkent Medical Academy, Tashkent, Uzbekistan
}

Key words: evoked cognitive potentials, cognitive impairment, chronic cerebral ischemia.

Abstract. Significant differences were identified during this study in ECP values of patients with chronic cerebral ischemia compared to normal age range. Change of evoked cognitive potentials was observed in healthy individuals as evidenced by change of maximum amplitude of cognitive potentials in frontal lead in simple tests and normalization of topographic distribution of evoked cognitive potentials upon increased level of challenge of cognitive task. Use of P300 method for measuring evoked cognitive potentials allowed identifying significant changes in electric activity of brain in patients with chronic cerebral ischemia and mild cognitive impairment of various natures. Although, these changes were qualitatively similar, changes in evoked cognitive potentials in patients with mild cognitive impairment disorders of varying nature had quantitative differences upon use of tests measuring various modality and level of difficulty of cognitive task.

Introduction. Diagnosis of cognitive impairment and study of pathologic mechanisms of their formation is an important neurophysiologic problem. Therefore, investigators targeted studying cognitive impairment $(\mathrm{CI})$ both in neurologic damage $[1,4,5]$ and a number of other diseases and risk factors, such as hypertension, metabolic syndrome, diabetes, atherosclerosis, and etc. [1, 5, 7].

Cognitive or the so-called endogen potentials reflect electric processes caused by brain activity. Neuropsychological investigation tools, patient's self-estimation and reports by close relations are used conventionally in diagnosing cognitive impairment. Existing investigation methods allow comprehensive assessment of magnitude and severity of cognitive changes. However, increasingly more attention has been recently drawn at techniques objectively assessing cognitive damage. Up-to-date technology developed lately includes method of evoked cognitive potentials or P300. High sensitivity of this technique allows early and objective identification of cognitive impairment, which also serves as a tool for monitoring effectiveness of therapy $[2,6]$.

Currently, Evoked Cognitive Potentials method has not yet been widely applied in clinical practice, including neurology [5]. Hence, one of the objectives of studying cognitive impairment is to introduce method of evoked acoustic cognitive potentials in diagnostics and rehabilitation of neurologic patients, including those with chronic cerebral ischemia.

Purpose of Study: investigate specificities of evoked acoustic cognitive potentials P300 in patients with chronic cerebral ischemia.

*e-mail:madjidova1@yandex.ru
Materials and Methods: study results included comprehensive analysis of data obtained via assessment of 302 patients with CCI, 1st and 2nd grade discirculatory encephalopathy (DE), hospitalized in Neurology Department of RCH No1, CCH SSRC (State-Stock Railway Company) "Uzbekistan Temir Yullari", private clinic "Spectra Neurology" named after N.M.Madjidov, and GMS clinic renamed as Neuromed Service in 2010-2013.

Based on sex distribution of patients, number of male study participants significantly prevailed female patients (165 (54.6 $\pm 2.8 \%)$ versus 137 $(45.4 \pm 2.9 \%$, respectively); $\mathrm{p}<0.05)$. Mean age was $61.3 \pm 0.3$ years, varying from 43 to 69 years.

The largest age group consisted of patients at the ages of $60-69(225 ; 74.5 \%)$, whereas the smallest had $43-49$ years of age $(5 ; 1.7 \%)$ (Pic. 1$)$.

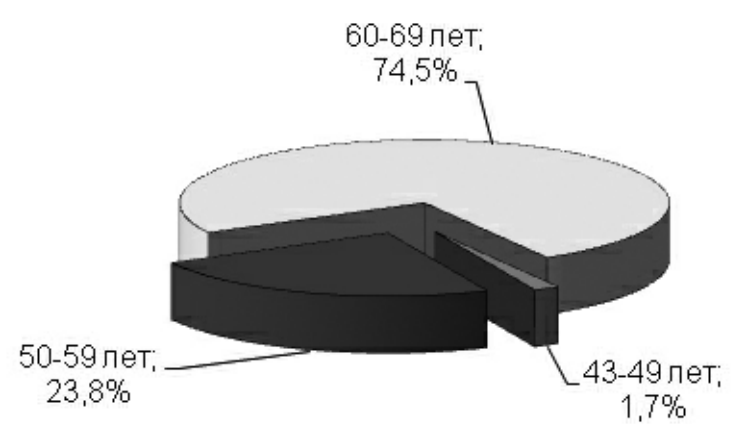

Pic. 1: Age distribution of patients

Exclusion criteria were as follows: age less than 35 and above 75, 3rd stage CCI, encephalopathy of other causes, stroke, diabetes, epilepsy, organic cerebral and spinal diseases (congenital, demylinating, degenerative, tumors), blood diseases, and autoimmune disorders. 
Diagnosis of MCI (Mild Cognitive Impairment) was made in accordance with ICD-10 and Levin's Classification (2006) based on patient history data, thorough clinical and neurologic evaluation, evaluation of cognitive functions, and magnetic-resonance imaging (MRI).

Patient distribution in groups was conducted in accordance with Levin's Classification for MCI (2006). First group consisted of 133 patients with amnesic type of MCI and the second group had 169 patients with multi-functional MCI.

Analysis of age and sex distribution of patients in groups revealed that, there is no association between type of MCI and age and sex of the patients, as both amnesic and multi-functional MCI are similarly seen more among males and those above 60 .

Recording and processing evoked cognitive potentials (ECP) was implemented on a personal computer using electroencephalographic analyzer software named Neurosoft EEG-5 (Ivanovo city). Upon examining patients with P300, series of verbal and non-verbal optic stimuli were presented and patients reacted to recognized significant stimuli by pressing a button. Ratio of significant and insignificant stimuli was 1:4. Duration of stimulus was 550 msec and frequency of stimuli was once per second. Simple and complex tests were conducted. Recording ECP was done using 19 standard leadings based on the scheme of 10-20 with the use of two reference ipsilateral ear electrodes. Artifact rejection was conducted using additional channels of EOG, ECG and EMG. Average of evoked potentials was calculated both for significant and insignificant stimuli, number of correct and incorrect answers were counted. Analysis period was $1 \mathrm{sec}$. Changes in N200 and P300 peaks of frontal, central, and parietal leadings were quantitatively analyzed. Amplitude and latency were calculated for all leadings. Maximum positive component with latency $\geq 300$ msec was considered as P300. Maximum negative component preceding P300 peak by no less than $60 \mathrm{msec}$ with latency $\geq 180 \mathrm{msec}$ was considered as $\mathrm{N} 200$.

$30(11.2 \%)$ healthy individuals (mean age $52.2 \pm 0.9$ years) without any objective signs of CCI and any health complaints were enrolled into the study for adequate assessment of cognitive impairment.
Study Results: neuropsychologic evaluation data revealed that, patients with MCI may be divided into two groups based on the features of cognitive disorder.

First group (MCI, amnesic type) had primary memory disorders. In addition to primary memory changes, these patients had other disorders characteristic for temporo-parieto-occipital (TPO) zone damage (disturbances in spatial gnosis and nominal component of speech) in combination with frontal subcortical disfunction and executive function disorders.

In second group (MCI, multi-functional type), profile of cognitive impairment was characterized by inhibition of mental processes and clear disorders of attention, initiation of mental actions, conceptualization, dynamic praxis, and control over voluntary activities, i.e., parietal subcortical syndrome.

Normal ECP values should be established first, in order to correctly understand the changes found in various diseases involving ECP. A detailed analysis of qualitative features of ECP was performed in control group consisting of healthy individuals, who had some changes in ECP parameters, which may be due to natural process of involution. In control group, normal deviation of stimulus perception did not affect N200 peak parameters. Increasing difficulty of cognitive task resulted in prolongation of LP peak of N200 regardless of modality of stimulation. Upon complication of verbal cognitive task, amplitude of peak of N200 did not change, whereas complication of non-verbal cognitive task resulted in lowering of amplitude of N200 peak in frontal leading.

Analysis of ECP parameters in control group in simple tests demonstrated a trend towards change of maximum P300 amplitude to frontal leading. In complicated tests "normalization" in distribution of peak of P300 was observed (maximum amplitude in parietal leading is specific to young ages). Normalization in distribution of peak of P300 in complicated tests among control group patients may possibly be explained by activation of functional reserves, responsible for cognitive processes evoked by more active involvement in a specific task, whereas in simple tests the tasks are implemented automatically.

A correlation between peak amplitude of P300 in frontal and central leadings and parameters of attention, initiation of mental activities, and number of 
perseverations is identified in control group in simple tests. Those who less successfully implement tests checking abovementioned functions had higher amplitude of P300 in frontal leading. These findings may evidence that disorders involving frontal lobe of brain present with habituation phenomenon as expressed by higher amplitude of ECP (i.e., patients accept a repetitive stimulus as a new one).

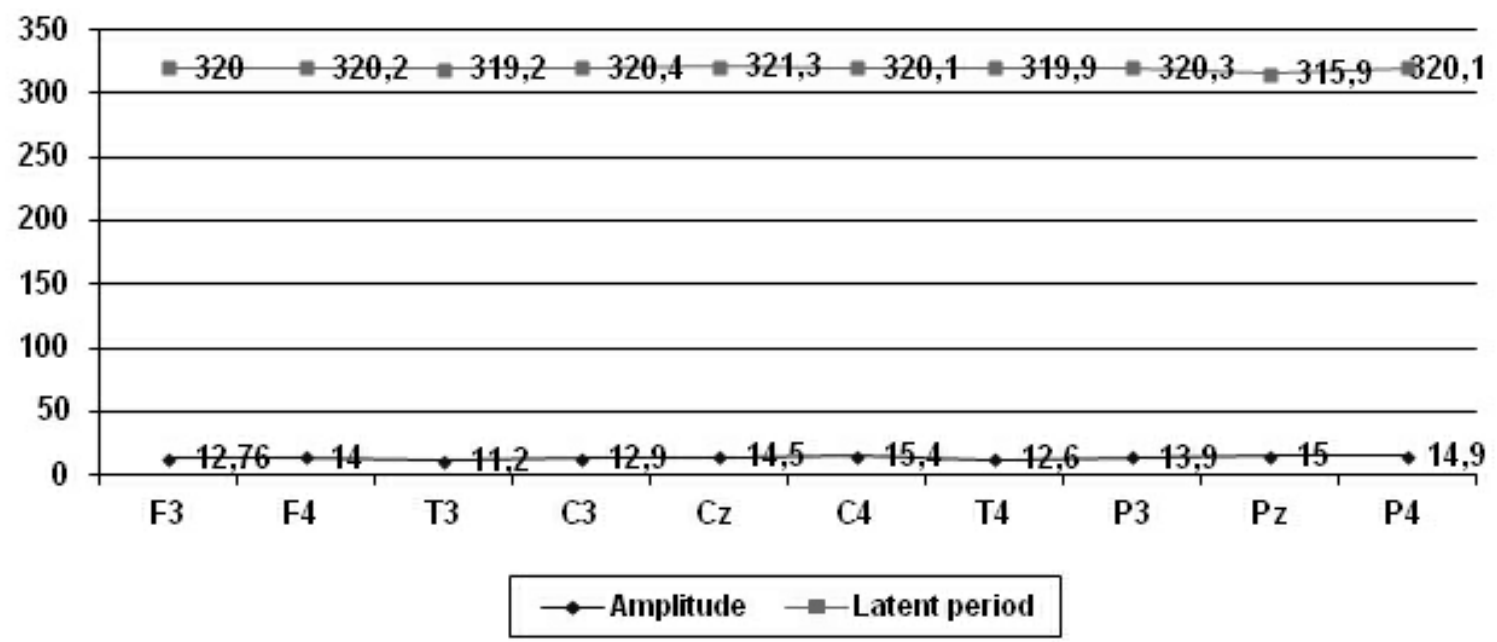

Fig. 1: Qualitative features of P300 peak in control group of older healthy individuals

Slight evening-out of MPA in simple tests in healthy individuals may be caused by changes in interactions between hemispheres occurring due to physiological involution processes. Upon increasing cognitive load, however, activity of relevant hemisphere also increases and differences in peak amplitude of P300 becomes more evident, demonstrating retention of compensatory reserves of mental activity.

Significant prolongation of FP ECP in both MCI groups versus normal values was observed, which correlates with neurodynamic changes found in neuropsychological evaluation.

Patients of Group 1 had different N200 values than norm range (higher peak amplitude of N200 was observed in parietal leading upon verbal stimulation and in frontal leading upon non-verbal stimulation). Also, patients of this group had higher peak amplitude of N200 in frontal leading upon non-verbal stimulation compared to second group, which allows assuming presence of more serious dysfunction of temporal lobe mainly in non-dominating hemisphere in patients of second group compared to first group. Higher values of peak amplitude of N200 in parietal leading upon verbal stimulation in patients of first group compared to normal values should be evaluated in line with neuropsychological findings. In this case, the rise in peak amplitude of N200 is a sign of damage in stimulus-recognition process and comparison of stimulus to its template in memory, which is combined with primary memory disorders in this group of patients.

Analysis of impact of modality of stimulation on N200 peak parameters in simple tests in first group revealed, that peak amplitude of N200 was higher in verbal stimulation than in non-verbal one (as opposed to patients of second group). Our findings may possibly be explained by development of concurrent pathologic process in amnesic type of MCI, resulting in dysfunctions of dominant hemisphere.

These assumptions are further confirmed by neuropsychological test findings: patients of this group had symptoms of spatial disorders and disorders of nominal component of speech, showing dysfunction of left parietal and left temporal lobes.

Analysis of LP of N200 peak in complicated verbal cognitive task in patients of first group demonstrated that this value remains unchanged, whereas it is prolonged in patients of second group. Possibly, in patients of first group, neurodynamic component of cognitive processes and speed of intellectual operations are damaged to a lower degree than those in second group.

As opposed to patients with multi-functional type of MCI, equal distribution of amplitude of P300 (Fig. 2) was observed in the group of patients with amnesic type of MCI and similar findings were obtained in the study conducted by N.N.Kobersky 
[2003] with patients who had Alzheimer's Disease (AD).

MPA of peak of P300 in first group was observed in frontal leading in complicated verbal test (Pic. 2). On one hand, this fact may be a manifestation of a staged process (in majority of cases of $\mathrm{AD}$ frontal lobe involves in the pathologic process later than other cerebral lobes and in MCI stage retention of
MPA in frontal lobe is still possible). On the other hand, increased peak amplitude of P300 in frontal leading may reflect disorders related to recognition of repeating stimuli and degradation of habituation phenomenon as a result. It is possible that combination of these two factors is the actual cause for increase in amplitude in frontal leading in patients of first group, which presents in form of MPA.
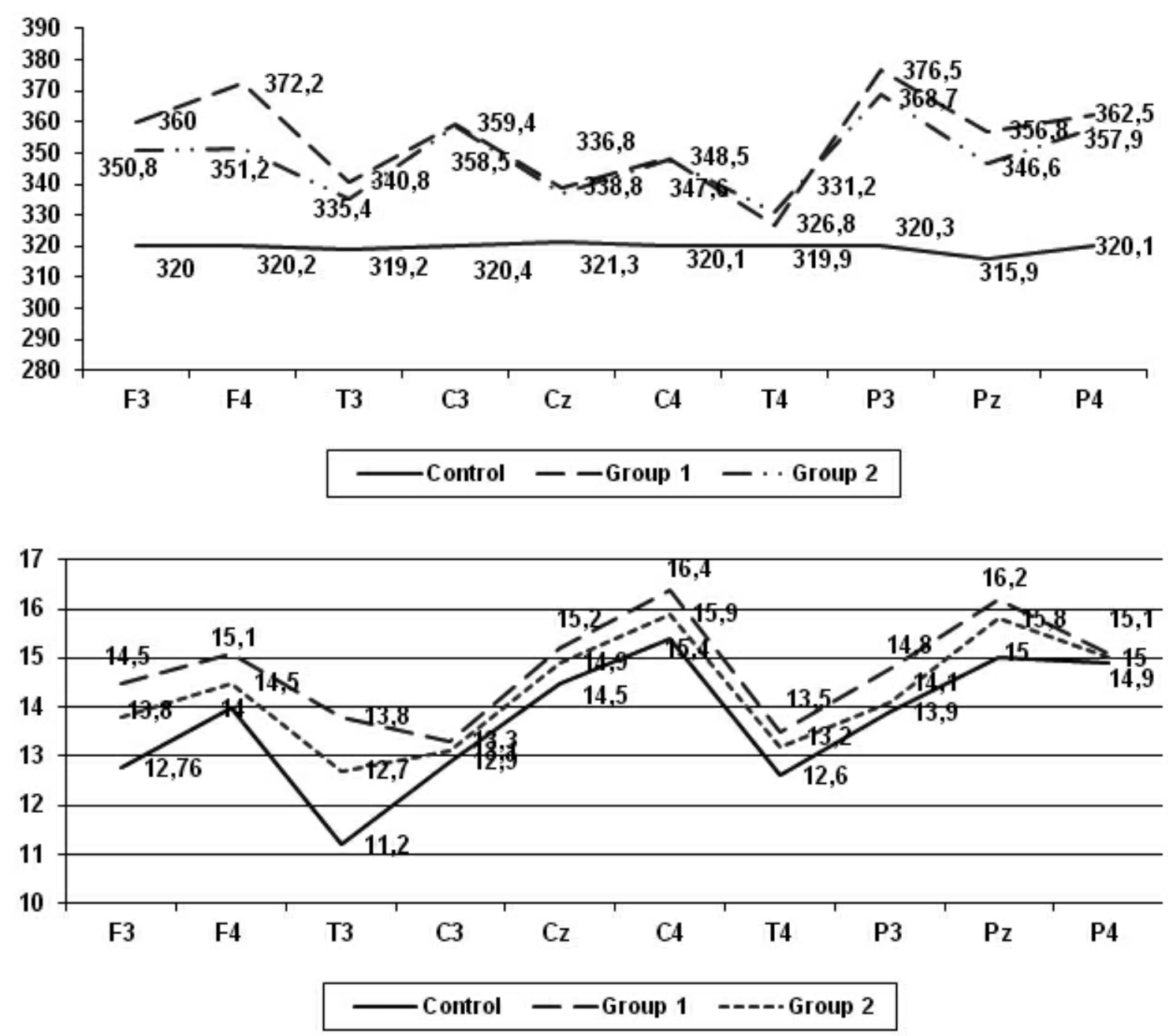

Fig.2: Comparative Evaluation of Qualitative Features of Peak of P300

Thus, it was identified, that slight smoothing of asymmetry between hemispheres and displacement of maximum amplitude of ECP in frontal leading, which disappears upon increase of cognitive load, probably due to activation of compensatory reserves. Analysis of peak values for N200 and P300 depending on modality and difficulty of cognitive task has shown primary involvement of anterior parts of brain in age-related physiological involution process.

In both groups of MCI, prolongation of latent periods of ECP was noted, which correlates with identified neurodynamic changes in neuropsycho- logical assessment.

Identified qualitative differences between the groups confirm possibility of concurrent development of neurodegenerative process in patients with MCI of amnesic type, which engages sub-dominant hemisphere along with the dominant one. This way, patients in this group are at increased risk of mixed dementia in future.

\section{Conclusions:}

1. Primary memory changes similar to those in Alzheimer's Disease are observed in amnesic type of MCI along with frontal subcortical dysfunction and neurodynamic disorders. This group of patients is characterized by 
changes of evoked cognitive potentials both in verbal and non-verbal stimulation in parietal leading. Interhemispheric asymmetry is retained in frontal leading in verbal test.

2. A clear neuropsychological syndrome is observed in multi-functional type of MCI, primarily caused by frontal subcortical dysfunction and neurodynamic disorders with secondary memory changes. Identified qualitative changes in parameters of evoked cognitive potentials (change of amplitude and prolongation of latent period, absence of interhemispheric asymmetry) allows to assume general morphofunctional nature of cognitive damage

\section{REFERENCES}

1. Бачинская Н.Ю. Синдром умеренных когнитивных нарушений // НейрoNews. 2010. - №1. - С. 12-17.

2. Гнездицкий В.В., Корепина О.С. Атлас по вызванным потенциалам мозга. - Иваново: Прес- Сто, 2011. - 532 с.

3. Гнездицкий В.В., Кошурникова Е.Е., Шахпаронова Н.В Роль компьютерной ЭЭГ и Р300 при анализе постинсультной афазии различного типа // Материалы XII Междунар. конф. "Актуальные направления в неврологии: сегодня и завтра". - Судак, 2010. - С. 178-184.

4. Гнездицкий В.В., Куликова С.Н., Кошурникова Е. Е. Особенности ЭЭГ и Р300 в оценке когнитивных нарушений. Функциональная диагностика. // Неврология. - 2009. and higher degree of deterioration of compensatory capacity in cognitive disorders.

3. In order to identify features of cognitive syndrome in MCI, it is necessary to analyze parameters of not only P300 peak, but early component of N200 as well with the use of test checking changes in modality of stimulation and difficulty of cognitive task.

4. Analysis of evoked cognitive potentials is an informative method that is supplementary to clinical and neuropsychological investigations in diagnostics of cognitive changes in MCI and analysis of its pathophysiological mechanisms.

\section{- №3. - С. 43-49.}

5. Коберская Н.Н. Клинико-электрофизиологические характеристики когнитивных нарушений при болезни Паркинсона и симптоматическом паркинсонизме: Дис. ... канд. мед. наук. - Москва, 2003. - 149 с.

6. Кропотов Ю.Д. Количественная ЭЭГ, когнитивные ВП мозга человека и нейротерапия. - Донецк: Заславский,2010. - 512c.

7. Golob E.J., Johnson J.K., Starr A. (2002) Auditory eventrelated potentials during target detection are abnormal in mild cognitive impairment. // Clin. Neurophysiol. - 2002. vol.113(1). - P.151-161.

\title{
PEЗЮМЕ
}

\section{ОСОБЕННОСТИ КОГНИТИВНЫХ ПОТЕНЦИАЛОВ Р300 ПРИ ХРОНИЧЕСКОЙ ИШЕМИИ ГОЛОВНОГО МОЗГА}

\author{
${ }^{1}$ Проф. Маджидова Е.Н., ${ }^{2}$ Хайдарова Д.К. \\ ${ }^{1}$ Ташкентский педиатрический медииинский институт \\ ${ }^{2}$ Ташкентская медицинская академия
}

В ходе работы были выявлены существенные отличия параметров когнитивных вызванных потенциалов у пациентов с хронической ишемией головного мозга от группы возрастной нормы. Были выявлены особенности изменения когнетивных вызванных потенциалов у здоровых в виде смещения максимума амплитуды когнетивных вызванных потенциалов в лобные отведения в простых пробах и нормализация топографического распределения когнетивных вызванных потенциалов при усложнении когнитивной задачи. Применение метода исследования когнетивных вызванных потенциалов Р300 позволило выявить существенное изменение электрической активности головного мозга у пациентов с хронической ишемией головного мозга и умеренными когнитивными расстройствами различного характера. Причем, если количественно эти изменения были схожи, то при использовании тестов на различную модальность и сложность когнитивной задачи, изменения когнетивных вызванных потенциалов у пациентов с умеренными когнитивными расстройствами различного характера отличались качественно.

Ключевые слова: когнитивные вызванные потенциалы, когнитивные нарушения, хроническая ишемия головного мозга. 


\title{
XÜLASə
}

\section{BAŞ BEYNIN XRONIKİ İSEMIYASI ZAMANI P300 KOQNITIV POTENSİALLARIN XÜSUSIYYYOTLORI}

\author{
${ }^{1}$ Prof. Mocidova Y.N, ${ }^{2}$ Xaydarova D.A. \\ ${ }^{1}$ Daşkənd pediatrik tibb institutu, Daşkənt, Özbəkistan; \\ ${ }^{2}$ Daşkənd tibb akademiyası, Daşkənd, Özbəkistan
}

Tədqiqat işi zamanı baş beynin xroniki işemiyası olan xəstələrdə yaş norması qrupu ilə müqayisədə törədilmiş koqnitiv potensialların (TKP) parametrlərinin əhəmiyyətli fərqi aşkarlanmışdır. Sağlamlarda sadə sınaqlarda TKP-ın maksimum amplitudlarının alın aparmalarına tərəf yerini dəyişməsi və koqnitiv çalışmaların çətinləşdirilməsi zamanı TKP-ın topoqrafik yayılmasının normallaşdırılması şəklində TKP-ın dəyişikliklərinin xüsusiyyətləri aşkarlanmışdır. P300 TKP-ın tədqiqat metodunun tətbiqi baş beynin xroniki işemiyası olan xəstələrdə baş beynin elektrik aktivliyinin əhəmiyyətli dərəcədə dəyişmələrini və müxtəlif xarakterli orta qabarıqlı koqnitiv pozulmaları aşkar etməyə imkan vermişdir. Bununla belə əgər koqnitiv çalışmaların müxtəlif modal1 və çətinlikli testlərindən istifadə zamanı kəmiyyət baxımığından bu dəyişikliklər oxşar olmuşdurlarsa, müxtəlif xarakterli müaliyim koqnitiv pozulmaları olan xəstələrdə TKP-ın dəyişiklikləri keyfiyyət baxımından fərqlənmişdir.

Açar sözlor: törədilmiş koqnitiv potensiallar, koqnitiv pozulmalar, baş beynin xroniki işemiyası.

Redaksiyaya daxil olub: 10.03.2014

Çapa tövsiya olunub: 10.04.2014

Rəyçi: t.e.d., prof. R.K.Şiraliyeva 